\title{
TEADMISE ESILETULEMINE VÕÕRKEELETUNNI MULTIMODAALSES SUHTLUSES
}

\author{
Eva Ingerpuu-Rümmel \\ Tartu Ülikool
}

\begin{abstract}
Kokkuvõte. Keeletunni diskursusel on kindel eesmärk - omandada uusi teadmisi ja oskusi sihtkeele kohta. Sellises suhtlussituatsioonis osaleb tavaliselt rohkem kui kaks inimest. Nii on õpetaja üheks peamiseks ülesandeks koordineerida osalejate tegevust võimalikult tõhusal moel ning saada sel viisil tagasisidet õpilaste teadmiste kohta. Eesmärgi saavutamiseks ja kõikide osaliste koostöö sujumiseks kehtivad tunnis suhtlusnormid. Need aga mõjutavad osalejate sõnaliste, prosoodiliste ja kehaliigutuslike modaalsuste kasutamist. Artikkel käsitleb juhtumit, kus õpilased soovivad teadmisi väljendada, kuid nende tegevust piirab suhtlusnorm - ühe õpilase vastamisõigus. Analüüsi aluseks olev videolõik on filmitud kõrgkooli loengus, kus õpiti eesti keelt võõrkeelena. Diskursusanalüüsi ja mikroetnograafilise lähenemise kombineerimisel saadud tulemused näitavad, et vaatlusalused õpilased leiavad viisi, kuidas oma teadmisest ning vastamisvalmidusest märku anda. Õpilased kasutavad selleks peamiselt liigutuslikke modaalsusi. Üks õpilane väljendab normile allumisest tulenevat pinget, mis avaldub üksnes mitmesugustes kehaliigutustes. Õpilaste tegevus annab õpetajale olulist teavet, kuidas suhtlust juhtida.
\end{abstract}

Märksõnad: diskursusanalüüs, suhtlusnormid, multimodaalne suhtlus, võõrkeeleõpe

\section{Sissejuhatus}

Eesti haridussüsteemis peetakse oluliseks võimaldada mitme võõrkeelega tutvumist juba põhi- ja keskkoolis. Seejärel jätkatakse keelte õppimist ülikoolis või keeltekoolis. Nii põhiharidust kui kõrgharidust andvates asutustes on tavapäraseks õppevormiks teadmiste kooskonstrueerimine rühmas, mille tegevust koordineerib õpetaja. Kui õpilased soovivad saavutada sihtkeeles hea suhtlemisoskuse, siis on oluline uurida, milline suhtlus 
toimub selles tunnis, kus nimetatud pädevuse omandamisega tegeletakse. Juba 1970ndatel hakati rääkima keele õppimises suhtluse kui terviku uurimisest (Adger 2001: 503). Keeleõppe diskursust analüüsides peab teadlane arvestama hulga nähtustega, mis avaldavad üksteisele mõju. Diskursus ise on samuti tegevus ja vastasmõjuga suhtlus ühiskonnas, nagu väljendab diskursuseuurija Teun van Dijk (1997: 13). Diskursusanalüüs võimaldab arvestada suhtluse mitut laadi modaalsustega, milleks on väljendumisel näiteks sõnad ja grammatika, prosoodilised ilmingud ning kehaliigutused (Tenjes jt 2010: 26). Seega saab ka õpperuumis toimuvat analüüsida õpetaja ja õpilaste vahelise multimodaalse suhtlusena ${ }^{1}$. Joan Kelly Hall on toonud välja suulise suhtlustegevuse kujundajad:

1) osalejad (ingl participants) - kõik interaktsiooni liikmed;

2) ümbrus (ingl setting) - ruumilised, ajalised ja füüsilised tingimused;

3) sisu (ingl content) - mis tuleb jutuks või millest ei räägita;

4) eesmärgid (ingl purposes) - sotsiaalsed ja kognitiivsed funktsioonid;

5) osalemisstruktuurid (ingl participation structures) - vooruvahetus, rollid ja osalejate õigused;

6) tegevusüksus (ingl act-sequence) - kronoloogiline järjestus (ingl chronological ordering); alustamised (ingl openings), üleminekud (ingl transitions), lõpetamised (ingl closings); juhendid (ingl formulae) (Hall 1993: 152, viidatud Dalton-Puffer 2007: 19 järgi).

Halli jaotus sobib iseloomustama ka võõrkeeletundi. Osalejateks on tavaliselt õpetaja ja õpilased ning sisuks peamiselt õpitavat keelt ja kultuuri puudutavad nähtused, millega tegeletakse enamasti klassiruumis laua taga istudes kindlal kellaajal (ümbrus). Põhiliseks eesmärgiks on teatud teadmiste ja oskuste omandamine rühmas kindla ajaperioodi vältel. Osalemisstruktuuridest võib uurija jälgida näiteks seda, kuidas toimub õpilaste sõnavõtmine ning milline mõju on õpetaja kui tunnitegevuste

1 Termin multimodaalne suhtlus tuli kasutusele robotitega suhtlemisel (Lemon jt 2001). 
koordineerija rollil. Tunni alguses tervitamine on näiteks esimene tegevusüksus.

Nii suure hulga nähtuste koosesinemise uurimiseks kasutavad uurijad videosalvestust ning mikroetnograafilist lähenemist. Just keeleõppe keskkonna mikroanalüüs aitab välja tuua võimalikke probleeme, mis takistavad õpilastel keele omandamist (Tannen 1993). Carolyn Temple Adger leiab, et mikroetnograafiline analüüs on aidanud mõista, milline mõju on mitteverbaalsel käitumisel ja ajastamisel klassiruumi diskursuses õpilaste edule õpingutes (Adger 2001: 508). Seetõttu innustavad teadlased ka õpetajaid ise oma tundide diskursust analüüsima (McCarthy 1991).

Klassiruumis toimuvat ei ole Eestis multimodaalse suhtlusena peaaegu uuritud. Artikkel esitab ühe juhtumi mikroetnograafilise analüüsi, mis on osa siinkirjutaja doktoriõpingute uurimistööst. Uurimus käsitleb võõrkeeletunni diskursust kõrgkoolis. Ka artikli autor leiab, et tunnis esile tulevate modaalsuste funktsioonide ning nende seoste analüüsimine aitab õpetaja ja õpilaste suhtlust paremini mõista ning annab panuse keeleõppe metoodikate arengusse.

Siinkirjutaja loodab aidata õpetajatel täita neile seatud ootusi, mille on ilmekalt sõnastanud Nira Hativa (2000: 213): „Nii peab õpetaja sillutama „kuldse raja”, õpetades sellises tempos ja tasemel, mis sobib suuremale osale õpilastest klassis, ning kandes hoolt, et parematel õpilastel ei oleks igav ja et kõige madalama tasemega õpilased ei tunneks liiga suurt frustratsiooni." Käesoleva artikli eesmärgiks on näidata, kuidas õpilased käituvad olukorras, kus teadmiste kooskonstrueerimisel kehtib suhtlusnorm ja õpilased peavad ootama sõnavõtmise järjekorda.

Uurimuse jaoks videosalvestatud kõrgkooliloengutest on siin käsitletud ühte suhtlusepisoodi, kus osalejate väljendumisel kasutatud modaalsused - sõnad ja grammatika, prosoodilised ilmingud ning kehaliigutused - võimaldavad teha järeldusi teadmiste kooskonstrueerimist mõjutavate tegurite kohta. Episoodis piirab õpilaste teadmiste väljendamist suhtlusnorm. Konkreetne episood on valitud seetõttu, et siin võib näha mitut võimalust, 
kuidas õpilased tulevad toime suhtlusnormi seatud piirangutega ning kuidas õpilased annavad märku teadmisest just peamiselt kehaliigutustega, mitte sõnadega. Üks õpilane väljendab ka pingeid, mis tulevad esile just liigutusliku modaalsuse kaudu. Artikli autor soovib analüüsiga esile tuua kehaliigutuste märkamise vajaduse, mis võimaldab õpetajal otsustada, kuidas suhtlust suunata.

\section{Keeleõppe diskursuse struktuur ja suhtlusnormid}

Klassiruumi diskursuse uurimisel on teadlaste huvikeskmes olnud vooruvahetus (ingl turn-taking) ehk suhtluses osalejate sõnavõtmise järjekord (nt McHoul 1978, Lörcher 1986, Markee 2000 ja Dalton-Puffer 2007). Vooruvahetust inimsuhtluses käsitlesid juba Ameerika teadlased Harvey Sacks, Emanuel Schegloff ja Gail Jefferson, kes töötasid välja vestlusanalüüsi meetodi 1960. aastate lõpus ja 1970. aastate alguses. Vestlusanalüüsi meetod võimaldab analüüsida suhtlustegevust. Sacks jt (1974) kasutasid inimestevahelise suhtluse jäädvustamiseks audiolindistusi. Videosalvestustehnika areng ja teadlastele kättesaadavaks muutumine on avardanud võimalusi uurida $\mathrm{ka}$ inimestevahelise suhtluse visuaalselt tajutavaid modaalsusi. Mõned autorid leidsid juba 1970.-1980ndatel, et kehaliigutused on inimeste vestluses samuti vooruvahetuse kujundajad (Duncan 1972, Sacks jt 1974, Duncan ja Fiske 1985).

Õpetajate ja õpilaste kehaliigutuste analüüsile klassiruumis hakati 20. sajandi lõpus üha rohkem tähelepanu pöörama. Näiteks Gene H. Lerner (1995) on kasutanud uurimiseks videosalvestamist, mis võimaldab tal $\mathrm{ka}$ üksnes visuaalselt tabatavaid modaalsusi analüüsida. Nii on klassiruumi suhtluse mikroanalüüsiga tegelevad autorid hakanud süsteemselt kehaliigutusi uurimisel arvesse võtma ning käsitlevad põhjalikult nende funktsioone diskursuse kulgemises (vt nt Lazaraton 2004, Kääntä 2005, Lehtimaja ja Merke 2005, Poveda 2005 ja Hellermann 2006). Gene H. Lerner (1995) analüüsis, kuidas õpetaja loob oma vooru üles ehitades erinevaid võimalusi õpilaste osa- 
luseks põhikoolitunnis ning transkriptsioone lugedes võib märgata õpilaste aktiivset osavõtmissoovi, mida nad väljendavad näiteks käetõstmisega. Leila Kääntä (2005) uuris aga keskkooliõpilaste keeletundi ning leiab, et mõnikord võivad õpilased loobuda sõnavõtmisest, kuigi neile on võimalus antud. Mõlemas artiklis tuleb esile, kui oluline on õpetaja ülesanne koordineerida tunni ajal toimuvat suhtlust.

Mõned klassiruumi suhtlust uurinud teadlased leiavadki, et sõnavõtmist reguleerivad suhtlusnormid (ingl interactional norms v interactional rules) (Adger 2001, Merola 2004 ja DaltonPuffer 2007), st suhtluses osalejatel on rollid ja sellele vastavalt jaotuvad ka õigused. Tihti märgitakse seoses klassiruumi diskursusega, et õpetajaroll sisaldab endas rääkimiseesõigust ning õigust anda teistele luba sõnavõtmiseks (Dalton-Puffer 2007: 20). Niisiis on suhtlusnormid osalejate vahel kujunenud otsused, mis puudutavad suhtlemisega seotud õigusi ja kohustusi. Klassiruumi diskursuses esiletulevad normid avalduvad konkreetsete modaalsuste kasutamise abil, näiteks õpilase nimetamise kaudu talle sõnaõiguse andmine või õpilase käetõstmine vastamise või küsimise loa saamiseks. Käetõstmist on uurinud mitmed teadlased (McHoul 1978, Sahlström 2002 ja Shepherd 2010). Shepherd (2010: xi) leiab, et käetõstmise võimaluse abil jagavad õpetaja ja õpilased kontrolli sõnavõtmise õiguse ja kohustuse üle.

Õpilane saab teadmisest märku anda peale liigutuse näiteks käetõstmise - ka muude modaalsuste kaudu, kas või vastust kõva häälega üle klassi hõigates. Teadmiste väljendamist ja vigade parandamist on klassiruumi diskursuses uurinud näiteks Mondada (1995), He (2004), Paoletti ja Fele (2004), Foster ja Ohta (2005), Dalton-Puffer (2007). Need teadlased on uurinud alla 18-aastaste laste ja noorte tunde, v.a Foster ja Ohta (2005), kes vaatlesid täiskasvanuõpet. Nimetatud artiklites ja teostes on autorite põhitähelepanu suunatud sõnade, grammatika ning prosoodia uurimisele. Kehaliigutusi ei analüüsita põhjalikult ega süsteemselt. Christine Dalton-Pufferi mahukas uurimus (selles osales seitse Austria kooli ja 14 klassi) esitab hea ülevaate teadmiste konstrueerimisel tekkivate vigade parandamise ja tagasiside eri tüüpi olukordadest (Dalton-Puffer 2007). Ta analüüsib 
neid olukordi vooruvahetuse seisukohast. Ta rõhutab oma teoreetilises käsitluses ka suhtlusnormide olulisust klassiruumi diskursuses.

Mõned autorid (Hall 1998, Paoletti ja Fele 2004) toovad välja, et õpetaja juhtimine võib tunnis osalejates tekitada pinged. Hall (1998) uuris õpetaja ja põhikooli õpilaste suhtlust hispaania keele klassis ning ta leiab, et kui õpetaja annab mõnele õpilasele rohkem sõna kui teistele, siis see mõjutab viimaste enesetunnet ning usku oma võimetesse keelt omandada. Paoletti ja Fele (2004) väidavad, et kui õigused on klassiruumis asümmeetriliselt jaotunud - õpetaja on klassivestluse juhtija, siis võib selline olukord olla pingete allikaks. Paoletti ja Fele (2004) usuvad, et põhjalikku uurimist väärivad klassiruumis ilmnevad pinged, mis tekivad mõttevahetuse toimumise korra kontrollimisel.

Suhtlusnormid ise ei ole ainsad klassiruumis pingete tekitajad. Teadmiste kooskonstrueerimise käigus õpilaste individuaalsetest erinevustest (kultuuriline päritolu, tunnis kasutatava keele oskuse tase) tekkivaid pingeid on uurinud näiteks Patricia A. Duff (2002). Ta uuris keskkooli erinevaid ainetunde ning leidis, et aktiivsemat ja passiivsemat sõnavõtmist põhjustavad näiteks õpilaste keeleoskus (st oskus rääkida keelt, mida tunnis suhtlemisel kasutatakse), aga ka kultuuriliste erinevuste tunnetamine võrreldes teiste õpilastega (Duff 2002).

Õpilaste enesetundele võib mõju avaldada ka õpetaja üldine väljendusstiil. Elena Buja (2009) on analüüsinud kirjaliku tagasiside põhjal õpilaste arvamusi, kuidas õpetaja mitteverbaalne käitumine mõjutab nende motivatsiooni. Buja leiab, et õpetaja saab õpilaste tagasisidet arvestades ja enda mitteverbaalset käitumist muutes kasvatada nende soovi tundides aktiivselt osaleda.

Käesolev artikkel analüüsib keeleõppe sündmust inimsuhtluses esinevatest modaalsustest lähtudes. Jälgides, kuidas õpetaja ja õpilased kasutavad modaalsusi, saame aimu suhtlusnormi olemasolust. Ühtlasi näeme, millisel moel norm mõjutab teadmiste kooskonstrueerimist. Artiklis analüüsitakse ühe suhtlusepisoodi näitel, kuidas ja millistes modaalsustes avalduvad õpilaste soov oma teadmisi näidata ning püüe normist tulenevate pingetega toime tulla. Nii õpilased kui õpetaja väljenduvad episoodi jook- 
sul peamiselt verbaalsete ja prosoodiliste modaalsuste abil ning mitmesuguste kehaliigutustega (nt miimika, käeliigutustega). Kui õpetaja on ühele õpilasele vastamisõiguse andnud, siis väljendavad ülejäänud õpilased end peamiselt liigutuslike modaalsuste abil. Väga oluline on õpetaja tundlikkus ja tõlgendusvõime nii õpilaste verbaalsete kui ka mitteverbaalsete väljenduste suhtes (Hativa 2000: 14), millele siinkirjutaja loodab tähelepanu pöörata suhtlusepisoodiga, mis on valitud suuremahulise korpuse analüüsi tulemusena esile tulnud juhtumite seast. Suhtlusnormidest juhindumisel tekkivate pingete õigeaegne märkamine ja maandamine võib kasuks tulla klassis parema õhkkonna kujunemisele ning õpilase motivatsioonile keelt õppida.

\section{Meetod ja uurimismaterjal}

Uurimistöö põhineb Tartu Ülikooli multimodaalse suhtluse andmebaasi (MUSU korpuse) interaktiivsete suhtlussituatsioonide (ISU) allkorpuse materjalidel, konkreetselt on analüüsimaterjaliks ühes Eesti ülikoolis aastatel 2009-2011 videosalvestatud keeletunnid. Uurimistöö subjektideks on täiskasvanud inimesed, kes on andnud nõusoleku uuringutes osalemiseks. Inimeste andmete kaitse on tagatud.

Eesti keele võõrkeelena loengute filmimiseks on kasutatud kahte videokaamerat. Uurimuses osalenud õpetajad räägivad eesti keelt emakeelena. Kõikides loengutes suhtlesid õpetaja ja õpilased peamiselt õpitavas keeles. Filmiv ja vaatlev uurija ei sekkunud tunni tegevustesse ning ülejäänud osalejad ei pöördunud filmimise ajal tema poole.

Töö esitab detailse analüüsi kaudu olulise näite multimodaalse suhtluse kasutamisest võõrkeeletunni diskursuses. Artiklis analüüsitava videolõigu pikkus on 37 sekundit. Videomaterjali transkribeerimisel on kasutatud Jeffersoni (2004) transkriptsioonimärke, mida on kohandatud ja osaliselt modifitseeritud konkreetse suhtlusepisoodi selgemaks esitamiseks. Lisaks on transkriptsioonis kasutatud tähtedega tähistamist tunnis osalejate pärisnimede asemel ning lühendeid $v$ ja $p$ sõnade vasak ja 
parem asemel (vt lisa 1). Selles suhtlusepisoodis esinevad kõik kolm väljenduseks kasutatavat põhimodaalsust: sõnad ja grammatika, prosoodia ning kehaliigutused. Kvalitatiivses analüüsis jälgitakse tähenduse loomise protsessi osalejate modaalsuste kaudu ning pööratakse tähelepanu, kuidas suhtlusnorm avaldab mõju suhtlussituatsioonis osalejatele.

\section{Suhtlusepisoodi analüüs}

Artiklis analüüsitavas suhtlusepisoodis osaleb lisaks õpetajale kümme üliõpilast. Kaheksale noorele on emakeeleks vene keel, ühele noormehele ukraina ja ühele neiule ungari keel. Transkriptsioonis on esitatud vaid õpetaja ja viie üliõpilase tegevus, sest ülejäänud osalejad jäid filmimisel mõlema kaamera (vt joonis 1 kaamerad K1 ja K2) ulatusest välja.

Artiklis on suhtlusepisoodi paremaks esitamiseks kasutatud peale transkriptsiooni ka joonist ning fotosid. Joonis 1 näitab õpetaja ja õpilaste paiknemist klassiruumis. Videolt lõigatud fotod 1-7 illustreerivad esitatud transkriptsiooni. Fotodel on tunnis osalejate näod peidetud anonüümsuse tagamiseks.

Suhtlusepisoodi ajal harjutatakse liitsõnade moodustamist ja kasutamist. Õpilastel on selleks kirjalik harjutus, mida tehakse suuliselt koos. Parajasti otsitakse lauselünka liitsõna, mille teine sõnapool oleks -pärane.

Õpilased istuvad klassiruumi kahes küljes. Õpetaja (joonisel 1 tähistusega Õ) liigub episoodi jooksul tahvli ees. Uurija (joonisel 1 tähistusega $U$ ) viibib kahe ukse lähedal nurgas kaamera taga (joonisel 1 on kõik kolm ust tähistatud halli ristkülikuga). Õpilased on tähistatud tähtedega A kuni J. A, B, C, I, J on õpilased, kes jäävad kaamerate ulatusest välja. D, E, F, G, H on kaamerate vaateväljas olevad õpilased. 


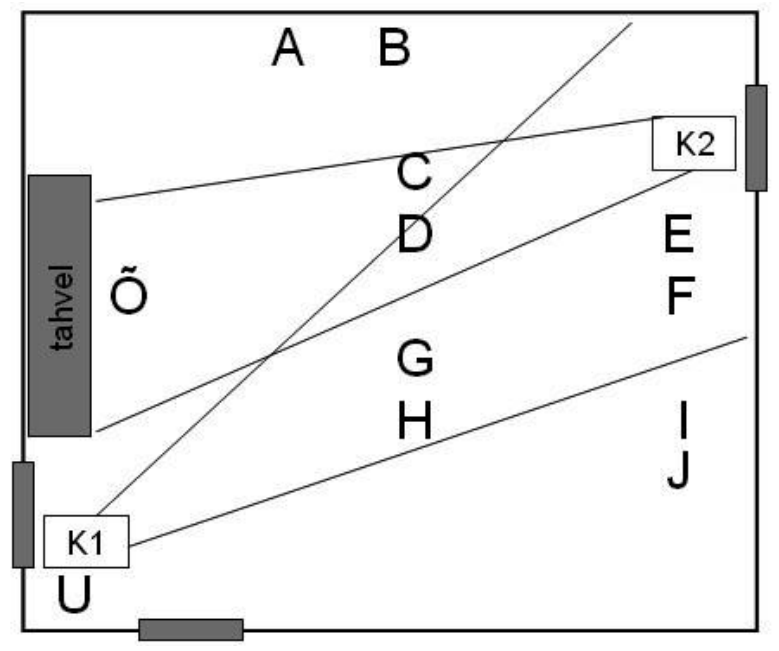

Joonis 1. Õpperuumi plaan.

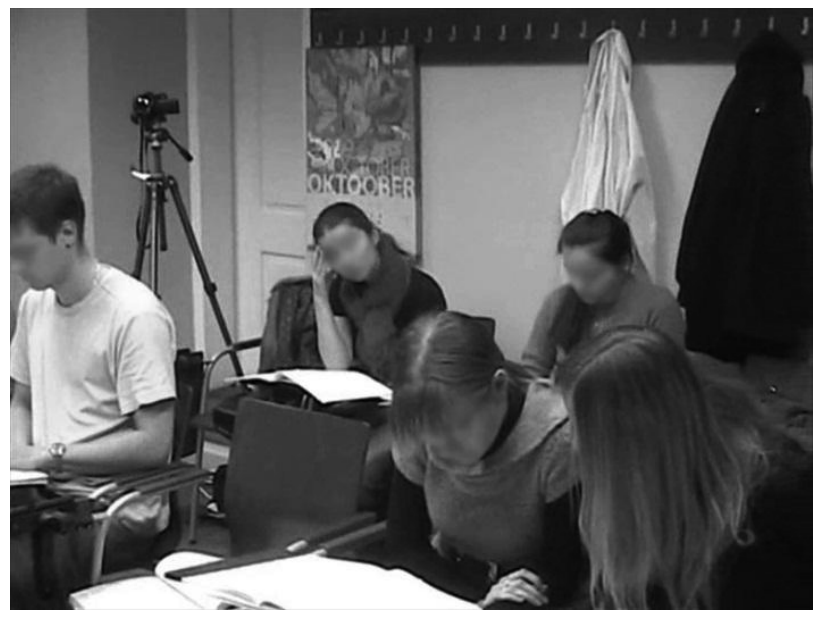

Foto 1. Vasakult paremale: esireas on õpilased D, G ja H; teises reas on õpilased $E$ ja $F$. 
Suhtlusepisoodis esinevad sõnad, prosoodilised nähtused ja liigutused on transkribeeritud voorudena vastavalt tegevuste järgnevusele (vt transkriptsioonimärke lisast 1). Numbrid tähistavad voorusid. Sama vooru jooksul kahe või enama inimese sõnaliste, prosoodiliste ja liigutuslike modaalsuste ajalise kattumise esitamiseks on kasutatud nurksulgusid ja topeltnurksulgusid. Topeltnurksulud aitavad eristada, millisel hetkel milliste inimeste modaalsused kattuvad. Transkriptsioonis esinev nimi on muudetud. Õpilased A, B ja D on meessoost. Ülejäänud üliõpilased (C, E, F, G, H, I ja J) ning õpetaja on naissoost. Liigutuste kirjeldamisel kasutatud väljend käelaba lõikab märgib, et serviti käelaba liigub vertikaalteljel suunaga ülalt alla. Kõigi kümne üliõpilase tähistamiseks on kasutatud lühendit ÜÕ.

1. Õ: Diana kuidas see järgmine lause on? olgugi?

((vaatab H poole ja siis töövihikusse, mida käes hoiab))

2. H: olgugi et see oli lihtsalt eee

3. Õ: [((tõstab pilgu ja vaatab $\mathrm{H}$ poole $))]$

E: $\left[{ }^{\circ}\right.$ suurepärane ${ }^{\circ}$ ((vaatab H ja Õ poole)) ((p käsi lehvitab näo ees edasi-tagasi, küünarnukk lauale toetatud))]

4. Õ: [noo mis sinna sobiks nendest sõnadest?] ((pilk püsib H-l))

E: [((tõstab kätt, mis läheb üle ringutuseks, ja tõmbab käe tagasi))]

5. H: tööpakkumine ((vaatab Õ poole))

6. Õ: [ei aga mis seal peaks nüüd] olema mingi [[selline sõna mille: mille: ee = ((koputab v käe sõrmedega avatud vihikusse, pilk liigub ruumis teistele ÜÕ-le))]]

G: [((näitab pastakaga $\mathrm{H}$ vihikus mingit kohta))]

E: $\quad$ [[((hakkab sõrmedega kiiresti vehkima))]]

Õ: [[= teine sõnapool] liitsõna mis lõpeb sõnaga pärane $]]$ ((pilk liigub H-le, v käelaba lõikab 4 korda))

G: [((näitab pastakaga uuesti $\mathrm{H}$ vihikus mingit kohta))]

E: [[((painutab pöidlaga ükshaaval sõrmi ja tõmbab huuled sissepoole pingule, siis peidab pöidla rusikasse))]]

D: [((vaatab H poole ja siis Õ poole $))]$

7. H: aa

8. Õ: [et see oli ((pilk vihikusse))]

H: [((vaatab G vihikusse ja seejärel enda vihikusse))]

F: [((sügab v käega nina))]

E: [((haarab p käega sallist, kohendab seda ja peidab lõua ja suu salli sisse))]

9. E: ((tõstab p käe kõrgele ja lehvitab))

10. Õ: kes teab?

((pilk liigub ringi, siis annab peanõksuga märku E-le))

11. E: suurepärane 
12. E:

[((silitab ja masseerib p käega v käe õlavart))]

D: ootuspärane (...) [ootuspärane]

Õ: $\quad$ [suurepärane] ootuspärane (.) jaa mõlemad siia sobivad

H:

13. D: omapärane

14. Õ: ((noogutab ja vaatab vihikusse))

[((vaatab G vihikusse) $)]$

jah

((heidab pilgu vihikusse))

Järgnevatel fotodel on mõned õpilase E tegevused. Iga foto juures on näidatud, milline voor transkriptsioonis vastab pildil nähtavale liigutusele.

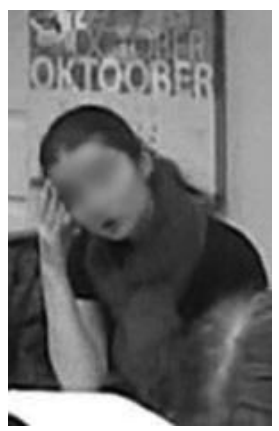

Foto 2. Õpilane E (voor 3).

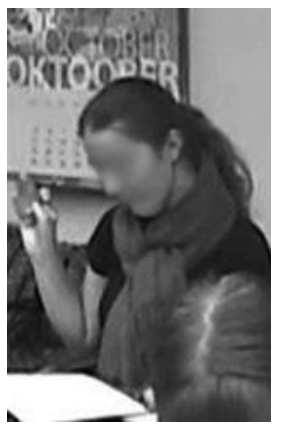

Foto 5.

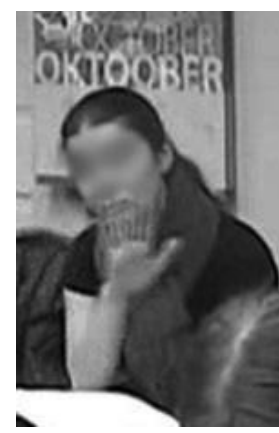

Foto 3.

Õpilane E (voor 3).

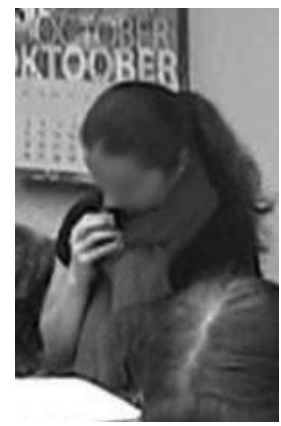

Foto 6.

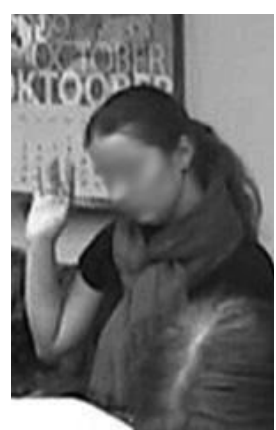

Foto 4.

Õpilane E (voor 6).

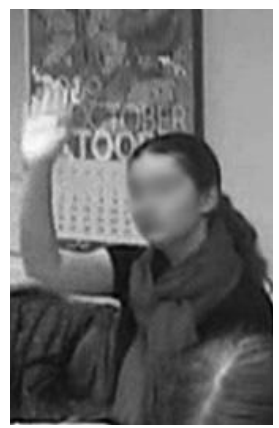

Foto 7.

Õpilane E (voor 6). Õpilane E (voor 8). $\quad$ Õpilane E (voor 9).

Suhtlusepisoodi ajal otsitakse töövihikus olevasse harjutusse sobivaid liitsõnu. Õpetaja annab vastamisõiguse ühele 
õpilasele, öeldes tema nime ning vaadates tema poole (voor 1). Õpilane H, kes peab vastama, alustab lause lugemist, kuid ei oska lõpetada (voor 2). Vastust teab aga õpilane E, kes istub teises reas. Ta sosistab sõna „suurepärane” ning lehvitab kätt oma näo ees, kuid ei tõsta seda kõrgele (voor 3). Õpetaja ei reageeri E käitumisele. On võimalik, et ta ei märka seda või ei soovi sel hetkel talle tähelepanu pöörata. Mõne meetri kaugusel istuv E on püstiseisva õpetaja vaateväljas, kuid õpetaja mikroliigutustest on näha, et tema tähelepanu on keskendunud eelkõige H-le: õpetaja vaatab $\mathrm{H}$ poole (voorud 1 ja 3 ). Õpetaja jätkab $\mathrm{H}$ abistamist ning viitab, et valida tuleb etteantud sõnade seast (voor 4). Õpilane H pakubki sõna „tööpakkumine” (voor 5), kuid õpetaja leiab, et sinna tuleb leida liitsõna, mille teine sõnapool oleks -pärane (voor 6). Samal ajal jälgib ta teiste üliõpilaste tegevusi, sest tema pilk liigub ruumis ringi (voor 6). H kõrval istuv $\mathrm{G}$ näitab talle kaks korda mingit kohta vihikus samal ajal, kui õpetaja räägib (voor 6). Seejärel ütleb õpilane H: „Aa”, (voor 7). Õpetaja annab H-le veel ühe võimaluse (voor 8), korrates osa lausest, millesse sobiv sõna leida tuleb. Kuid $H$ ei vasta. Ta vaatab vaid $G$ vihikusse ja siis oma vihikusse (voor 8). Õpetaja pilk liigub ruumis ringi ka teistele üliõpilastele samal ajal, kui ta esitab küsimuse „Kes teab?” (voor 10). Vahetult enne, kui õpetaja küsib: „Kes teab?” (voor 10), tõstab E käe ja lehvitab (voor 9). Õpetaja annabki peanõksuga E-le märku, et nüüd võib vastata (voor 10). E pakub sõna „suurepärane” (voor 11). Kohe võtab sõna ka õpilane D, kes ütleb kaks korda: „Ootuspärane”, (voor 12). Kuigi mõlema õpilase pakutud sõnad öeldakse välja kiiresti üksteise järel, kuuleb õpetaja neid sõnu ning kinnitab, et mõlemad variandid sobivad lausesse (voor 12). Seejärel pakub D veel ühe sõna „omapärane” (voor 13), mis õpetaja arvates samuti sobib (voor 14). Õpilane H vaikib ja vaatab teiste vastamise ajal naabri $G$ vihikusse (voor 12 ).

Õpilaste peamiselt liigutuslikest modaalsustest on näha, et mõni neist sooviks oma teadmist väljendada (olgu vastus õpetaja arvates sobiv või mitte), kuigi neil ei ole vastamisõigust kuni õpetaja küsimuseni „Kes teab?” (voor 10). Õpilane D vaatab vaheldumisi $\mathrm{H}$ ja siis õpetaja poole (voor 6). D vastab kohe (voor 
12), kui õpetaja on loa andnud. Õpilane G püüab aga oma naabrit H-d aidata ning talle õiget kohta või konkreetset sõna harjutuses ette näidata, pastakaga $\mathrm{H}$ vihikus ühte kohta kaks korda osutades (voor 6). Kõige aktiivsemalt väljendub modaalsuste abil õpilane $E$, kes püüab esialgu vastust ette sosistada (voor 3). Ta annab oma vastamissoovist käega märku neljal korral (voorud 3, 4, 6, 9). Iga kord on käeliigutus erinev. Esimesel korral on see tagasihoidlik, sest küünarnukk on lauale toetatud ning käsi liigub näo ees edasi-tagasi (voor 3). Teisel korral tõstab ta käe kõrgele, kuid see liigutus kattub õpetaja väljendusega: õpetaja pilgu suund koos sõnalise väljendusega viitab, et vastamisõigus on jätkuvalt õpilasel H (voor 4). E muudab oma liigutuse ringutuseks (voor 4). Seejärel hoiab ta küünarnukki laual, ent vehib kiiresti sõrmedega (voor 6). Lõpuks tõstab ta käe uuesti kõrgele ja lehvitab (voor 9).

Õpilased D, G ja F ei väljendu verbaalselt sel ajal, kui H-1 on vastamisõigus, ja nad teevad ainult üksikuid kehaliigutusi. Õpilane F vaatab episoodi jooksul kogu aeg enda ees olevasse vihikusse. Ta ei võta sõna ka siis, kui õpetaja on kõigile vastamiseks loa andnud. Kuid õpilane E alustab sosinaga ning teeb hulgaliselt kehaliigutusi, milleks on põhiliselt käeliigutused, pilk ja miimika. Ta proovib õpetaja tähelepanu köita kaks korda kätt tõstes (voorud 3 ja 4). Kuid see ei õnnestu ja nii väljendab ta kärsitust tõstetud käe sõrmedega kiiresti vehkides (voor 6). Seejärel hakkab ta sõrmi ükshaaval pöidlaga murdma ning peidab pöidla lõpuks peopessa. Samal ajal tõmbab ta ka huuled sissepoole pingule (voor 6). Tal on soov oma teadmist näidata, kuid ta peab selle alla suruma. Siis haarab ta parema käega sallist, kohendab seda ning peidab lõua ja suu salli sisse (voor 8). Olukord on E jaoks ebamugav, sest vastamisõigust piirav suhtlusnorm tekitab temas pingeid. Arvestades, et E on juba mitmel korral üritanud teadmisest märku anda, kuid pole vastata saanud, siis võib lõua ja suu peitmine salli sisse (voor 8) viidata ka loobumisele. Ometi tõstab ta järgmisel hetkel kohe käe kõrgele ja lehvitab (voor 9). Õpetaja annabki kõigile võimaluse sobivaid sõnu harjutuse lausesse pakkuda (voor 10). E pakub ühe sõna (voor 11) ning silitab ja masseerib seejärel parema käega oma vasakut õlavart (voor 
12). Kuna mikroanalüüs näitas, et $\mathrm{E}$ jaoks oli just lahenenud pingeline olukord, siis võib see liigutus tähendada nii rahustamist kui enese tunnustamist.

\section{Arutlus}

Võõrkeeletunnis osaleb sageli rohkem kui kaks inimest. Eesti ülikoolides tuleb ette ka selliseid olukordi, kus keele õppimist alustavas rühmas on 30-40 üliõpilast. Enamasti on rühmades siiski 10-20 õpilast. Sellises situatsioonis püüavad õpilased üheskoos õpetaja juhendamisel nii suulist kui kirjalikku väljendusoskust omandada. Et kõigil oleks võimalik teadmiste kooskonstrueerimises osaleda, tuleb kehtestada suhtlusnormid. Igal õpilasel peab olema võimalus aeg-ajalt sõna võtta selleks, et küsida õpitava sisu kohta, et harjutada parajasti õpitavat sõna või grammatilist nähtust või et avaldada juba olemasolevaid teadmisi. Õpilased ei saa rääkida kõik korraga, sest siis ei kuule õpetaja igaühe vastust või küsimust. Nii pöördub õpetaja õpilaste poole nimepidi või peanoogutusega või käega märku andes. Ühtlasi saavad teised aru, et nemad peavad oma sõnavõtmise järjekorda ootama. Kuid õpilane võib ka ise kätt tõsta ning vastamiseks, küsimiseks või harjutamiseks soovi avaldada (Merola 2004: 105). Käetõstmine on väga levinud põhi- ja keskkoolis, kuid seda kasutavad ka täiskasvanud ülikooli loengutes, kus on palju õpilasi, või näiteks teaduskonverentsidel pärast ettekannet küsimuste esitamiseks soovi avaldades.

Käesolevas artiklis analüüsitud keeletunnis osalevad kümme üliõpilast ja õpetaja. Vastamisõigus on vaid õpilasel $H$, sest õpetaja pöördub tema poole ning ütleb tema nime. Õpilane E tõstab neli korda kätt, enne kui tal vastata lubatakse. Õpetaja ei väljenda, kas ta märkab E märguandeid. Õpilane E on õpetajale üsna lähedal (mõne meetri kaugusel) ning püsti seisva õpetaja keha suunda ja vaatevälja ulatust arvestades võiksid $E$ tegevused talle nähtavad olla. Seetõttu on võimalus, et õpetaja on otsustanud esialgu E-le mitte reageerida, sest ta ootab vastust H-lt. Selline suhtluse organiseeritus võimaldab kõigile tunnis 
osalejatele enam-vähem võrdsed keeleoskuse arendamise tingimused. Kuid niisugune olukord tekitab pingeid õpilases, kes sõna võtta ei või, aga siiski tahaks seda teha.

Üldiselt pöörduvad keeleõpetajad tunnis suulist harjutust tehes järgemööda erinevate õpilaste poole, kuid õpilane, kelle kord parajasti on, ei pruugi tahta või osata vastata. Nii võib klassiruumi diskursuses tekkida hetk, mil teadmisi ei avaldata. Õpilane, kellel on vastamisõigus, hoopis vaikib või vastab mittesobivalt. Nii juhtub artiklis analüüsitud suhtlusepisoodis õpilase H-ga, kellel on vastamisõigus, kuid tema vastus õpetaja arvates ei sobi ning $\mathrm{H}$ ei paku rohkem variante. Teised õpilased aga kõval häälel sekkuda ei või. Kuid ühe õpilase - E - suhtlustegevusest on videol selgesti näha, et ta soovib oma teadmisi näidata ning sobivat vastusevarianti pakkuda. Ta püüab tähelepanu tõmmata käe tõstmisega ja sõna ette sosistades. Õpilase E kehaliigutused väljendavad ka pinget, mis tuleneb suhtlusnormi seatud piirangutest ja oma tahte allasurumisest. Ta vehib kiiresti sõrmedega, murrab sõrmi, tõmbab huuled sissepoole pingule ja kohendab salli, peites lõua ning suu selle sisse. Teiste õpilaste käitumine pingeid ei väljenda. Samuti ei ole võimalik aru saada, kas õpilane $\mathrm{H}$ tunneb ebamugavust, et ei oska harjutusse sobivat vastust leida. Kui arvestada, et õpetaja ülesandeks on tunni jooksul pidevalt jälgida õpilaste arusaamist ja huvi olemasolu (Hativa 2000: 202, 337), siis kolme õpilase (D, E, G) käitumine annab aimu nende teadmistest ning ühe õpilase $(\mathrm{H})$ väljendused raskustest. Ometi ei väljenda peale E ükski teine neljast videole jäädvustunud üliõpilasest, et õpetaja peaks kiirustama teistele sõna andmisega ja et sobiva vastuse ootamise ajal oleksid õpilastel $\mathrm{D}, \mathrm{F}, \mathrm{G}$ ja $\mathrm{H}$ pinged, mis võiksid mõjutada nende suhtumist konkreetsesse tundi (mille eest hoiatavad MacIntyre ja Gardner (1991)) või üldiselt eesti keele õppimisse.

Pinged võivad tekkida suhtlusolukorras, kus on palju inimesi koos ning pidevalt tuleb jälgida vestluse kulgu ning tabada õiget hetke enese väljendamiseks. Kui üks õpilane võib vastata, siis teised võivad kuulata ja kannatlikult oodata ning võtta sõna siis, kui neile on selleks tõepoolest luba antud (nagu seda teeb õpilane D). Neil on võimalus ka oma kaaslast aidata, nagu seda 
teeb õpilase $H$ naaber $G$, kes näitab pastakaga vihikus seda kohta, kust H peaks sobiva vastuse leidma. Samuti saavad õpilased püüda sõnaõigust saavutada kätt tõstes. Just nii teeb õpilane E. Kuid ta teeb veel midagi - sosistab sobiva vastuse ette. Selle tegevusega rikub ta suhtlusnormi, kuigi vaiksel häälel väljendatu ei pruugi õpetajale ja isegi H-le kuuldav olla. Selline käitumine on võrreldes kõvahäälse vastuse teatamisega justkui pehmem normi rikkumine, kuid võimaldab siiski teadmist väljendada.

Õpilastes tekkivad pinged võivad olla väga lühiajalised ning lõppeda hetkel, mil nad siiski saavad sõna võtta ja oma teadmist väljendada. Õpilase E käitumine analüüsitava suhtlusepisoodi lõpus (voor 12), mil ta pärast vastuse kõvahäälset väljaütlemist parema käega oma vasakut õlavart silitab ja masseerib, võib viidata rahunemisootusele. Kuid õpetajalt nõuab selline olukord suurt tähelepanelikkust. Ta ootab ühe õpilase vastust ja võib märgata samal ajal ülejäänud õpilaste käitumist. Ka suhtlusepisoodis vaatab õpetaja aeg-ajalt ruumis ringi samal ajal, kui ta ootab H-lt vastust. Liiga pikk (ja seda tunnetavad õpilased individuaalselt) tegelemine üheainsa õpilasega võib suhtluses osalejaid negatiivselt mõjutada. Analüüsitud suhtlusepisoodis väljendab pingeid üks õpilane - E. Seetõttu ei ole õpetaja niisuguses olukorras üksnes keele õppimise juhendaja ja abistaja rollis, vaid samuti suhtlustegevuste suunaja ning pingete reguleerija. Nii annab õpetaja suhtlusepisoodis võimaluse kõigil vastata. Ta küsib "Kes teab?" ning viipab peanõksuga E poole, kes on juba tõstnud käe kõrgele ja lehvitab seda hoogsalt.

Artiklis analüüsitud suhtlusepisoodist on näha, et suhtlusnorm, mis annab ühele õpilasele vastamisõiguse, on klassiruumis vajalik. See norm võib luua võimaluse õpilasele, kes muidu võtaks väga harva sõna. Nii peab kaasa mõtlema ja püüdma vastata ka see, kes muidu ei taha või ei oska kohe vastata. Erinevatele õpilastele sõna andes saab õpetaja tagasisidet. Ta saab teada, millistel õpilastel võib parajasti õpitava aineosaga raskusi olla ja millised õpilased tunnevad igavust (Hativa 2000: 337). Klassiruumis ringi vaadates ja vaikivate õpilaste kehaliigutusi jälgides on õpetajal võimalik otsustada, millal saabub hetk kõikide õpilaste kaasamiseks vastamisse, mis laseb ka pingetel vaibuda. 


\section{Kokkuvõte}

Artiklis esitatud analüüs näitab, et keeleõppe diskursust suunav norm ei tähenda üksnes seda, et üks õpilane võib õpetaja küsimusele vastata, vaid mõjutab ka väljendumiseks modaalsuse tüübi (nt kehaliigutuse või sõna) valimist. Suhtlusepisoodi analüüsil selgus, et õpilased leiavad oma teadmise avaldamiseks mitmesuguseid viise, sealjuures normi oluliselt rikkumata. Üks õpilane näitab pastakaga vastama pidavale naabrile õiget kohta vihikus, teine õpilane püüab vastust ette sosistada ning tõstab mitmel korral kätt. Nad ei saa oma teadmist väljendada kõvahäälselt. Seetõttu on kehaliigutused peamiseks modaalsuseks teadmisest märkuandmisel. Kui üks õpilane teisele ette sosistab, siis ka see on suhtlusnormi rikkumine, kuigi pisut pehmem kui üle ruumi vastuse hõikamine. Suhtlusepisoodis kasutab sosistamist vaid üks õpilane ühel korral, kõik ülejäänud teadmise väljendamised toimuvad liigutusliku modaalsuse kaudu. Niisiis võib keeletunnis kehtiv suhtlusnorm seada piiranguid õpilaste verbaalsele väljendusele.

Just sõnavõtmise õiguse puudumine võib õpilase panna pingelisse olukorda. Selleks et üks õpilane rühmast saaks keeleliselt areneda, peavad teised vahepeal vaikima. Pinged ilmutavad end samuti põhiliselt kehaliigutuste kaudu. Suhtlusepisoodis oli näha, kuidas üks õpilane peale tavapärase käetõstmise vehkis tõstetud sõrmedega kiiresti, murdis neid, tõmbas huuled sissepoole pingule.

Kui õpetaja peab püüdma pakkuda kõigile õppijatele võrdseid aineteadmiste arendamise võimalusi (Hativa 2000: 47), siis on suhtlusnormide kasutamine sõnavõtmise järjekorra kehtestamisel oluline. Sama tähtis on õpetaja jaoks jälgida, kas õpilaste käitumine väljendab pingeid, mis võivad tekkida sõnavõtmise järjekorra ootamisest ja soovist oma teadmisi näidata. Artiklis analüüsitud suhtlusepisoodis jälgis õpetaja õpilaste käitumist ning andis lõpuks kõigile loa vastamiseks. Kuigi üks õpilane väljendas pingeid vastamisõiguse ootamise ajal, sai õpetaja samal ajal tagasisidet, et vähemalt ühel õpilasel on harjutuse tegemisel raskusi. Õpetaja arvestas ka õpilasega, kes tundis pin- 
geid, ning tegi peanõksu just tema suunas, kui lubas küsimusega „Kes teab?” kõigil sõna võtta.

Vastamisõiguse puudumisest tulenevaid pingeid ei ole keeleõppes modaalsuste analüüsi kaudu veel põhjalikult uuritud. Suurema hulga sarnaste näidete uurimine võimaldaks õpetajal saada praktilisi lahendusi selliste olukordade juhtimiseks, kus üks õpilane on saanud sõna, aga ei oska või ei taha vastata ning kus teine õpilane soovib oma teadmist väljendada, kuid tal puudub selleks õigus.

\section{Tänuavaldus}

Artikkel on valminud Eesti Teadusfondi grandi nr 8008 osalisel toel. Autor avaldab tänu oma doktoriõpingute juhendajale dotsent Silvi Tenjesele väärtuslike kommentaaride eest.

\section{Aadress:}

Eva Ingerpuu-Rümmel

Eesti ja üldkeeleteaduse instituut

Tartu Ülikool

Jakobi 2

51004 Tartu, Eesti

E-mail: eva.ingerpuu-rummel@ut.ee

\section{Kirjandus}

Adger, Carolyn Temple (2001) "Discourse in educational settings". In Deborah Schiffrin, Deborah Tannen, and Heidi E. Hamilton, eds. The handbook of discourse analysis, 503-517. Malden, Oxford, and Carlton: Blackwell Publishing Ltd.

Buja, Elena (2009) "The influence of a teacher's non-verbal behaviour on students' motivation”. Bulletin of the Transilvania University of Braşov. Series IV: Philology and Cultural Studies 2, 51, 135-142.

Dalton-Puffer, Christiane (2007) Discourse in content and language integrated learning (CLIL) classrooms. Amsterdam, Philadelphia: John Benjamins Publishing Company. 
Dijk, Teun A. van (1997) "The study of discourse". In Teun van Dijk, ed. Discourse as structure and process. Discourse studies: a multidisciplinary introduction 1, 1-34. London, et al.: SAGE Publications.

Duff, A. Patricia (2002) "The discursive co-construction of knowledge, identity, and difference: an ethnography of communication in the high school mainstream". Applied Linguistics 23, 3, 289-322.

Duncan, Starkey J. (1972) "Some signals and rules for taking speaking turns in conversation". Journal of Personality and Social Psychology 23, 2, 283-292.

Duncan, Starkey J. and Donald W. Fiske (1985) Interaction structure and strategy. Cambridge: Cambridge University Press.

Foster, Pauline and Amy S. Ohta (2005) "Negotiation for meaning and peer assistance in second language classrooms". Applied Linguistics 26, 3, 402-430.

Hall, Joan Kelly (1998) "Differential teacher attention to student utterances: the construction of different opportunities for learning in the IRF". Linguistics and Education 9, 3, 287-311.

Hativa, Nira (2000) Teaching for effective learning in higher education. Dordrecht, et al.: Kluwer Academic Publishers.

He, Agnes Weiyun (2004) "Identity construction in Chinese heritage language classes". Pragmatics 14, 2-3, 199-216.

Hellermann, John (2006) "Classroom interactive practices for developing L2 literacy: A microethnographic study of two beginning adult learners of English". Applied Linguistics 27, 3, 377-404.

Jefferson, Gail (2004) "Glossary of transcript symbols with an introduction". In Gene H. Lerner, ed. Conversation analysis: Studies from the first generation, 13-23. Philadelphia: John Benjamins.

Kääntä, Leila (2005) "Pointing, underlining and gaze as resources of instructional action". Conference Proceedings. 2nd Conference of the International Society for Gesture Studies (ISGS) "Interacting bodies - Corps en Interaction” 15-18 June 2005. École normale supérieure Lettres et Sciences humaines. Lyon. Veebis <http://gesture-lyon2005. ens-lyon.fr/IMG/pdf/Kaanta.pdf >. Vaadatud 28.10.2011.

Lazaraton, Anne (2004) "Gesture and speech in the vocabulary explanations of one ESL teacher: A microanalytic inquiry". In Alexander Z. Guiora, Kathleen Bardovi-Harlig, and Zoltán Dörnyei, eds. Language Learning: A Journal of Research in Language Studies 54, 1, 79-117.

Lehtimaja, Inkeri et Saija Merke (2005) "Alternance des champs discursifs en classe". Conference Proceedings. 2nd Conference of the International Society for Gesture Studies (ISGS) "Interacting bodies - Corps en Interaction" 15-18 June 2005. École normale supérieure Lettres et Sciences humaines. Lyon. Veebis <http://gesture-lyon2005.enslyon.fr/IMG/pdf/Alternance_des_champs_discursifs_en_classe.pdf $>$. Vaadatud 28.10.2011. 


\section{Eva Ingerpuu-Rümmel}

Lemon, Oliver, Anne Bracy, Alexander Gruenstein, and Stanley Peters (2001). "The WITAS multi-modal dialogue system I". Proceedings 'EuroSpeech 2001'. Veebis <http://www-csli.stanford.edu/semlabhold/witas/es01.pdf $>$. Vaadatud 21.04.2011.

Lerner, Gene H. (1995) "Turn design and the organization of participation in instructional activities". Discourse Processes 19, 1, 111-131.

Lörscher, Wolfgang (1986) "Conversational structures in the foreign language classroom”. In Gabriele Kasper, ed. Learning, teaching and communication in the foreign language classroom, 11-22. Århus: Århus University Press.

MacIntyre, Peter D. and Robert C. Gardner (1991) "Language anxiety: its relation to other anxieties and to processing in native and second languages". Language Learning 41, 4, 513-534.

Markee, Numa (2000) Conversation Analysis. Mahwah, NJ: Lawrence Erlbaum.

McCarthy, Michael (1991) Discourse analysis for language teachers. Cambridge: Cambridge University Press.

McHoul, Alexander (1978) "The organisation of turns at formal talk in the classroom". Language in Society 7, 183-213.

Merola, Giorgo and Isabella Poggi (2004) "Multimodality and gestures in the teacher's communication". Lecture Notes in Computer Science, 101-111. Veebis <http://host.uniroma3.it/docenti/poggi/cursitopdf/ poggiteacher.pdf $>$. Vaadatud 19.04.2011.

Mondada, Lorenza (1995) "Analyser les interactions en classe: quelques enjeux theoriques et repères méthodologiques". In Bernard Py, ed. Intervention en groupe et interactions, 55-89. (Travaux Neuchâtelois de Linguistique (TRANEL), 22.) Neuchâtel: Institut de Linguistique Université de Neuchâtel.

Paoletti, Isabella and Giolo Fele (2004) "Order and disorder in the classroom". Pragmatics 14, 1, 69-85.

Poveda, David (2005) "Metalinguistic activity, humor and social competence in classroom discourse". Pragmatics 15, 1, 89-107.

Sacks, Harvey, Emanuel A. Schegloff, and Gail Jefferson (1974) "A simplest systematics for the organization of turn-taking in conversation". Language 50, 696-735.

Sahlström, Fritjof (2002) "The interactional organization of hand raising in classroom interaction". Journal of Classroom Interaction 37, 2, 47-57.

Shepherd, Michael Andrew (2010) "A discourse analysis of teacher-student classroom interactions". A dissertation presented to the Faculty of the USC Graduate School University of Southern California in partial fulfillment of the requirements for the Degree of Doctor of Philosophy (Linguistics). Veebis <http://digitallibrary.usc.edu/assetserver/ controller/item/etd-Shepherd-3879.pdf $>$. Vaadatud 28.10.2011.

Tannen, Deborah (1993) "What's in a frame? Surface evidence for underlying expectations". In Deborah Tannen, ed. Framing in discourse, 14-56. New York: Oxford University Press. 
Tartu Ülikooli Multimodaalse suhtluse uurimise grupi (MUSU) korpuse interaktiivsete suhtlussituatsioonide allkorpus (ISU). Veebis http:// www.murre.ut.ee/flee-korpused/. Vaadatud 02.07.2012.

Tenjes jt 2010 = Tenjes, Silvi, Triin Lõbus, Leila Kubinyi, Ingrid Rummo, Dmitri Kulakov ja Eva Ingerpuu-Rümmel (2010) „Multimodaalne suhtlus keeleõppe ja -kasutuse teenistuses". Eesti ja soome-ugri keeleteaduse ajakiri 1, 1, 21-40.

\section{Lisa 1. Transkriptsioonimärgid ja lühendid}

[ ]

nurksulud on kasutusel kahe või enama inimese sõnaliste, prosoodiliste ja liigutuslike modaalsuste ajalise kattumise esitamiseks

[[ ]] topeltnurksulud on kasutusel samas voorus esinevatest märkidest [ ] eristamiseks, kui ühe isiku sõnalised, prosoodilised ja liigutuslikud modaalsused kattuvad vooru alustanud isiku modaalsustega ajaliselt teistsugusel hetkel, võrreldes ülejäänud kattumistega

$=\quad$ näitab, et voor jätkub katkematult

(.) lühike paus

(...) pikk paus

(( )) topeltsulgudes on esitatud liigutused (miimika, pilk, liigutused käte ja kehaga)

? hääle tõus

$\circ \circ \quad$ sosinal öeldu on kirjutatud kahe märgi vahele

: $\quad$ sõna ühe hääliku tavapärasest pikemalt hääldamine

Õ onetaja

D, E, F, G, H õpilased

ÜÕ kõik tunnis osalenud üliõpilased

$\mathrm{p} \quad$ parem

v vasak

Abstract. Eva Ingerpuu-Rümmel: Displaying knowledge in the multimodal communication of a foreign language learning classroom. Language learning discourse has a certain goal - to acquire new knowledge and skills in the language studied. The teacher has as 


\section{Eva Ingerpuu-Rümmel}

a central role in coordinating participants' activities in effective ways and soliciting feedback about learners' knowledge. In order to regulate turn-taking, interactional norms are applied. These norms condition the use of modalities - body movements, verbal, and prosodic communication. The paper examines an instance where only one learner is supposed to answer. The analysis is based on a video of an episode in a university lecture where Estonian is taught as a foreign language. The research combines discourse analysis and the micro-ethnographic approach. The results show that the learners find a way to express their knowledge by using mainly body movements. One learner uses several body movements to express the tension caused by interactional norm. The learners' behaviour provides the teacher with important information on how to direct communication.

Keywords: discourse analysis, interactional norms, multimodal communication, foreign language learning 